\begin{abstract}
BACKGROUND: CC chemokine ligand (CCL)5 and its receptor CCR5 contribute to leukocyte migration into lungs of patients with diffuse lung diseases (DLD). Pharmacological regulation of CCL5 and CCR5 expression was therefore explored in bronchoalveolar cells obtained from patients with DLD.

Methods: Cells from 21 patients were co-cultivated in vitro with tumour necrosis factor- $\alpha$ and dexamethasone, cyclosporin A (CyA) or pentoxifylline. Chemokine mRNA expression and protein production was assessed by reverse transcription-polymerase chain reaction and enzyme-linked immunosorbent assay, respectively.

Results: Dexamethasone altered CCL5 mRNA expression and suppressed its protein levels. CyA inhibited chemokine mRNA expression but not protein production. Pentoxifylline did not affected chemokine expression. Both dexamethasone and CyA suppressed CCR5 mRNA transcripts.

Conclusion: In conclusion, while dexamethasone downregulates the CCL5 functional form, CyA and pentoxifylline have no effects on $\mathrm{CCL} 5$ protein. These data provide in vitro correlation for clinical applications of immunomodulators in therapy of DLD.
\end{abstract}

Key words: Dexamethasone, Cyclosporin A, Pentoxifylline, Sarcoidosis, RANTES, Glucocorticoids, Bronchoalveolar cells

\section{In vitro pharmacoregulation of CC chemokine ligand 5 and its receptor CCR5 in diffuse lung diseases}

\author{
Veronika Sekerova', Daniela Subrtova', \\ Frantisek Mrazek', Agata Gibejova', \\ Vitezslav Kolek ${ }^{2}$, Roland M. du Bois ${ }^{3}$ and \\ Martin Petrek ${ }^{1, C A}$
}

${ }^{1}$ Department of Immunology, and ${ }^{2}$ Department of Respiratory Medicine, Palacky University, I. P. Pavlova 6, CZ-775 20 Olomouc, Czech Republic ${ }^{3}$ Interstitial Lung Disease Unit, Royal Brompton Hospital, London, UK

\footnotetext{
${ }^{\mathrm{CA}}$ Corresponding Author

Tel: +420588442285

Fax: +420585415116

E-mail: petrekm@fnol.cz
}

\section{Introduction}

Chemokines (chemotactic cytokines) are low molecular weight proteins secreted by a variety of cells including leukocytes, epithelial cells, endothelial cells, fibroblasts and other cell types. ${ }^{1}$ These factors have been identified as attractants and activators of different types of blood leukocytes to sites of infection and inflammation. ${ }^{2}$ Acting via an array of Gprotein-coupled receptors, chemokines play an important role in the pathogenesis of numerous inflammatory diseases, including lung inflammatory diseases, and also other immunopathologies. ${ }^{3-5}$

Diffuse lung diseases (DLD) are characterised by accumulation of inflammatory cells resulting in pathological alveolar and interstitial inflammation. The progressive derangement of alveolar architecture, deposition of extracellular matrix components and loss of functional tissue follow this process. Activated leukocytes produce proteins with proinflammatory properties, among those chemokines. These mediators cause further recruitment of inflammatory cells from the circulation into the lung. ${ }^{6}$

The chemokine RANTES (regulated on activation, normal T-cell expressed and secreted), CC chemokine ligand (CCL) 5, is a CC chemokine originally thought to be a T-cell-specific sequence. ${ }^{7}$ Recently, a number of cells have been found to express CCL5 including platelets, monocytes, B cells, natural killer cells, epithelial cells, fibroblasts and endothelial cells. ${ }^{6}$ It has been demonstrated that CCL5 recruits and activates not only $\mathrm{T}$ cells, but also other leukocytes including basophils, eosinophils, mast cells, dendritic cells, monocytes and B cells. ${ }^{6,8}$ The studies from our group and others ${ }^{9-11}$ have provided important information on the role of CCL5 and its receptor CCR5 in the pathogenesis of DLD, especially pulmonary sarcoidosis. These studies have demonstrated that increased expression of CCL 5 and CCR5 mRNA contributes to the accumulation of lymphocytes in diffuse lung diseases acting in concert with other chemokines.

The glucocorticoids such as dexamethasone (Dx) are used as the drugs of the first-line in the therapy of DLD because of their anti-inflammatory and immunomodulatory effects. Their effect is based on the inhibition of transcription factor nuclear factor- $\kappa \mathrm{B} .{ }^{12}$ This process affects the expression of chemokine genes.

Besides corticosteroids, other more selective immunomodulatory drugs like cyclosporin A (CyA) have been studied and clinically used in treatment of DLD. ${ }^{13}$ CyA blocks T-cell function after alloantigen stimulation by inhibiting production of a number of cytokines such as interleukin-2, tumour necrosis 
factor- $\alpha$ (TNF- $\alpha)$ and granulocyte-macrophage colony stimulating factor. ${ }^{12}$ CyA has been already clinically tested in the therapy of sarcoidosis, but with contradictory results. ${ }^{13}$

Recently, immunomodulatory and anti-inflammatory properties of pentoxifylline $(\mathrm{Px})$ have been reported. ${ }^{14-16}$ This xanthine derivative is primarily used for the treatment of vascular diseases. However, an inhibitory effect of Px on the levels of TNF- $\alpha$ was demonstrated, ${ }^{15}$ which stimulated its first clinical use for the therapy of sarcoidosis. ${ }^{17}$

The effect of the aforementioned drugs on chemokine production has been studied before. However, other cell types of patients with other disorders than DLD were subjected to these modulators in vitro: for example, the effect of Dx on bronchial and epithelial cells of asthma patients was investigated. ${ }^{18,19}$ So far there has been little information about in vitro effect of Dx, CyA and Px on population of bronchoalveolar cells from the lung of patients with DLD. We wished to verify whether the beneficial therapeutic effect of immunomodulators on DLD is due to their inhibitory effects on chemokine, especially CCL5, mRNA expression and subsequent protein release by bronchoalveolar cells. The chemokine CCL5 and its receptor CCRS were chosen for these studies because of its relevance for pathobiological mechanisms of DLD.

\section{Materials and methods}

\section{Study population}

Bronchoalveolar lavage was performed according to our standard procedure ${ }^{20}$ in 21 patients with DLD. For diagnoses and laboratory characteristics, refer to Table 1.

Table 1. Clinical and laboratory data of 21 investigated subjects with DLD

\begin{tabular}{|c|c|}
\hline Age (years) & $46(25-69)$ \\
\hline \multicolumn{2}{|l|}{ Sex } \\
\hline Male & 6 \\
\hline Female & 15 \\
\hline \multicolumn{2}{|l|}{ Smoking } \\
\hline Smokers & 4 \\
\hline Non-smokers & 13 \\
\hline Ex-smokers & 4 \\
\hline BALF cell concentration $\left(10^{5} / \mathrm{ml}\right)$ & $2.6(0.4-4.6)$ \\
\hline \multicolumn{2}{|l|}{ BALF differential count } \\
\hline$\%$ Macrophages & $83.0(24.0-97.0)$ \\
\hline \% Lymphocytes & $17.0(0.0-63.0)$ \\
\hline$\%$ Neutrophils & $0.3(0.0-37.0)$ \\
\hline \% Eosinophils & $0.0(0.0-34.0)$ \\
\hline \% Basophils & $0.0(0.0-0.0)$ \\
\hline $\mathrm{BALF} \mathrm{CD} 4^{+} / \mathrm{CD}^{+}{ }^{+}$T-cell ratio & $1.8(0.5-16.1)$ \\
\hline
\end{tabular}

Data presented as median values (range, minimum-maximum). BALF, bronchoalveolar lavage fluid.

Diagnosis: sarcoidosis $(n=11)$, cryptogenic fibrosing alveolitis $(n=$

$3)$, lymphocyte alveolitis $(n=2)$, interstitial pneumonia $(n=2)$, extrinsic allergic alveolitis $(n=2)$, DLD after Cordarone $(n=1)$.
The study was performed with the approval of the Ethics Committee of the Medical Faculty of Palacky University Olomouc.

\section{Cultivation of bronchoalveolar cells}

The cells were isolated from bronchoalveolar fluid and washed twice in RPMI-1640 medium (USOL, Prague, Czech Republic). The recovered cells were cultivated in the concentration $1 \times 10^{6}$ cells in $1 \mathrm{ml}$ of RPMI-1640 medium with 8\% of bovine serum (ZD, Hustopece, Czech Republic), 100 U of Penicillin (Leciva, Praque, Czech Republic), $100 \mu \mathrm{g}$ of streptomycin (Leciva) and 7.5\% $\mathrm{NaHCO}_{3}$ (USOL). To investigate the effect of Dx, CyA and Px on chemokine expression, the drugs were added $30 \mathrm{~min}$ before TNF- $\alpha$ stimulation. ${ }^{18}$ The concentrations of drugs and of stimulator are presented in Table 2, where also their manufacturers are specified. The cultivation was performed at $37^{\circ} \mathrm{C}$ and $5 \% \mathrm{CO}_{2}$. After $21 \mathrm{~h}$ of cultivation (culture duration determined in preliminary experiments), the supernatant was separated and stored at $-80^{\circ} \mathrm{C}$ for further analysis. The suspension of cultured cells was centrifuged $(250 \times g, 8 \mathrm{~min})$, and the pellet was re-suspended in $1.5 \mathrm{ml}$ of $0.1 \%$ diethyl pyrocarbonate in phosphate-buffered saline and centrifuged twice $(250 \times g, 8 \mathrm{~min})$ for subsequent mRNA extraction.

\section{mRNA extraction and reverse transcription}

The final cell pellet was used to extract mRNA by means of biomagnetic separation-Dynabeads (Dynal, Oslo, Norway) as previously described. ${ }^{21}$ Briefly, 9.0 $\mu l$ of mRNA solution, obtained by biomagnetic separation, were incubated with $2.0 \mu \mathrm{l}$ of oligo $(\mathrm{dT})_{15}$ (Promega, Southampton, UK) for $5 \mathrm{~min}$ at $95^{\circ} \mathrm{C}$, and subsequently for $5 \mathrm{~min}$ at $4^{\circ} \mathrm{C}$. Reverse transcription was performed at $42^{\circ} \mathrm{C}$ for $60 \mathrm{~min}$ and the samples were heated to $80^{\circ} \mathrm{C}$ for $10 \mathrm{~min}$ to terminate the reaction. Each reaction contained $9.0 \mu \mathrm{l}$ of mRNA solution, $2.0 \mu \mathrm{l}$ of oligo $(\mathrm{dT})_{15}$ primer (Promega), $5 \mathrm{mM}$ of $\mathrm{MgCl}_{2}$ (Promega), $1 \mathrm{mM}$ of each deoxynucleotide triphosphate (Promega), $10 \mathrm{U}$ of avian myeloblastosis virus reverse transcriptase (Promega) and 10-20 U of RNAse inhibitor (Promega) in a total volume of $18 \mu \mathrm{l}$. The resulting cDNA was diluted fivefold in sterile water and stored at $4{ }^{\circ} \mathrm{C}$.

\section{Polymerase chain reaction}

Polymerase chain reactions (PCRs) were performed with oligonucleotide primers specific to CCL5, CCR5 and $\beta$-actin designed from the published cDNA sequences. ${ }^{11,22}$ The sequences of the primers were as follows: 5'-TCA TTg CTA CTg CCC TCT gC (CCL5 sense) and 5'-CCT AgC TCA TCT CCA AAg Ag (CCL5 antisense), 5'-gAT ggA TTA TCA AgT gTC AAg 
Table 2. Concentrations of drugs and number of evaluated cultures influenced by particular drugs

\begin{tabular}{|c|c|c|c|c|}
\hline \multirow[t]{2}{*}{ Drug } & \multirow[t]{2}{*}{ Concentration $/ \mathrm{ml}$ of culture ${ }^{a}$} & \multirow[t]{2}{*}{ Producer } & \multicolumn{2}{|c|}{$\begin{array}{l}\text { Number of } \\
\text { cultures }^{\mathrm{b}}\end{array}$} \\
\hline & & & mRNA & Protein \\
\hline TNF- $\alpha$ & $10 \mathrm{ng}^{18}$ & National Institute for Biological Standards, Potters Bar, UK & 16 & 15 \\
\hline Dexamethasone & $0.43 \mu \mathrm{g}^{18}$ & Sigma, St Louis, MO, USA & 14 & 14 \\
\hline Cyclosporin A & $10 \mathrm{ng}^{26}$ & Sandoz, Basel, Switzerland & 9 & 6 \\
\hline Pentoxifylline & $20 \mu g^{16}$ & Biotika, Slovenska Lupca, Slovakia & 4 & 6 \\
\hline
\end{tabular}

a Reference citations from which the in vitro dosage was adopted are included.

${ }^{b}$ Number of cultures available for studies of modulatory effect of particular drug.

T (CCR5 sense) and 5'-ggg CTg CgA TTT gCT TCA $\mathrm{C}$ (CCR5 antisense), and 5'-TCC TgT ggC ATC CAC gAA ACT ( $\beta$-actin sense) and $5^{\prime}$-gAA gCA TTT gCg gTg gAC gAT ( $\beta$-actin antisense). The predicted sizes of the amplified CCL5 and CCR5 CDNA products were 243 and 91 base pairs (bp), respectively; the size of the $\beta$-actin amplicon was $315 \mathrm{bp}$. The PCR reaction mix contained the sense and antisense primers $(0.25$ $\mathrm{mM}$ each), deoxynucleotide triphosphates $(0.2 \mathrm{mM}$ each; Promega), $1.5 \mathrm{mM}$ of $\mathrm{MgCl}_{2}$ (Promega), $1.25 \mu \mathrm{l}$ of PCR buffer 10x (Promega), $5 \mu \mathrm{l}$ of cDNA and $0.5 \mathrm{U}$ of Taq polymerase (Promega) in a total reaction volume of $13 \mu \mathrm{l}$. After initial denaturation ( $5 \mathrm{~min}$ at $95^{\circ} \mathrm{C}$ ), 36 cycles for CCL 5 and 32 cycles for $\beta$-actin were performed using MJR-Tetrad thermocycler (MJR, Waltham, MA, USA). The optimal number of amplification cycles for each gene was defined in order to reach the exponential phase of the amplification process. ${ }^{22}$ One cycle consisted of denaturation $\left(95^{\circ} \mathrm{C}, 45 \mathrm{sec}\right)$, annealing $\left(55^{\circ} \mathrm{C}, 45 \mathrm{sec}\right)$ and extension $\left(72^{\circ} \mathrm{C}, 90 \mathrm{sec}\right)$. The final extension $\left(72^{\circ} \mathrm{C}\right.$, $10 \mathrm{~min}$ ) was carried out and the reaction was terminated by chilling to $4^{\circ} \mathrm{C}$. A negative control reaction containing all components except template cDNA was set up with every PCR experiment. All determinations were performed in duplicate.

\section{Identification of PCR products, measurement and semi-quantification of CCL5 and CCR5 mRNA expression}

The amplification products were separated on $2 \%$ agarose gel (Agarose; Serva, Heidelberg, Germany) stained by ethidium bromide (Sigma, St Louis, MO, USA). The negative images of the gels on Polaroid type 665 film (Polaroid Corp., Cambridge, MA, USA) were scanned on a laser densitometer and the optical density (OD) values for the individual products were obtained (Image Master software; Pharmacia, Stockholm, Sweden). CCL5 (CCR5) mRNA expression was semi-quantified by normalising CCL 5 expression to $\beta$ actin. The chemokine/ $\beta$-actin optical density ratios (ODRs) were derived for each subject as previously described $^{22}$ (ODR = OD CCL5/OD $\beta$-actin for CCL5, or OD CCR5/OD $\beta$-actin for CCR5).

\section{Quantification of CCL5 protein production by enzyme-linked immunosorbent assay}

The concentration of immunoreactive CCL5 protein in cell culture supernatant was measured using commercially available solid-phase sandwich enzyme-linked immunosorbent assay (ELISA) (Quantikine ELISA assay; R\&D Systems, Abingdon, UK). Briefly, $100 \mu \mathrm{l}$ duplicates of cell culture supernatant or standard (recombinant human CCL5) were applied to wells of an ELISA tray pre-coated with a mouse monoclonal anti-human CCL5 antibody. After incubation ( $2 \mathrm{~h}$, room temperature), the wells were washed three times before addition of a horseradish peroxidase-conjugated goat-polyclonal anti-CCL5 antibody. Trays were incubated ( $1 \mathrm{~h}$, room temperature), washed and then chromogen and substrate solution (tetramethylbenzidine and hydrogen peroxide) was added. After incubation (20 min, room temperature), reactions were stopped by the addition of $2 \mathrm{M}$ of sulfuric acid and absorbance was measured at $450 \mathrm{~nm}$ using an ELISA-plate reader (Titertek Multiskan MCC/340; Labsystems, Vantaa, Finland). The data were processed by KIM-E software (USOL). The lower limit for the detection of CCL5 was 19.0 $\mathrm{pg} / \mathrm{ml}$.

\section{Statistical analysis}

The effect of studied drugs on CCL5 and CCR 5 mRNA expression and CCL5 protein production is expressed as an index of modulation, which normalises the data to the TNF- $\alpha$ stimulated values for mRNA and protein expression in cultures treated by studied drugs.

A paired $t$-test was employed to investigate differences in chemokine mRNA expression and protein production in modulated cell cultures in vitro. $p<$ 0.05 was considered statistically significant.

\section{Results}

To explore the effect of immunomodulators on CCL5 in DLD, bronchoalveolar cells were co-cultivated in vitro with TNF- $\alpha$ and Dx, CyA or Px. The results are summarised in Table 3. 
Table 3. Effects of Dx, CyA and Px on TNF- $\alpha$-induced CCL5 and CCR5 mRNA expression and CCL5 protein production in bronchoalveolar cell from patients with DLD

\begin{tabular}{|c|c|c|c|c|c|c|}
\hline Drug & Mean & Standard error of the mean & $p$ value & Mean & Standard error of the mean & $p$ value \\
\hline & \multicolumn{3}{|c|}{ CCL5 mRNA } & \multicolumn{3}{|c|}{ CCL5 protein } \\
\hline $\begin{array}{l}\text { Dexamethasone } \\
\text { Cyclosporin A } \\
\text { Pentoxifylline }\end{array}$ & $\begin{array}{l}0.80 \\
0.75 \\
1.06\end{array}$ & $\begin{array}{l}0.11 \\
0.09 \\
0.16\end{array}$ & $\begin{array}{l}0.09 \\
0.02 \\
0.80\end{array}$ & $\begin{array}{l}0.71 \\
0.97 \\
1.00\end{array}$ & $\begin{array}{l}0.04 \\
0.06 \\
0.07\end{array}$ & $\begin{array}{c}<0.01 \\
0.69 \\
1.00\end{array}$ \\
\hline & \multicolumn{3}{|c|}{ CCR5 mRNA } & \multicolumn{3}{|c|}{ CCR5 protein } \\
\hline $\begin{array}{l}\text { Dexamethasone } \\
\text { Cyclosporin A }\end{array}$ & $\begin{array}{l}0.78 \\
0.65\end{array}$ & $\begin{array}{l}0.07 \\
0.12\end{array}$ & $\begin{array}{l}0.02 \\
0.04\end{array}$ & & $\begin{array}{l}\text { Not evaluated } \\
\text { Not evaluated }\end{array}$ & \\
\hline
\end{tabular}

The modulatory effect is expressed as the index of modulation; for details, see methods.

Dx showed a suppressive effect on CCL5 transcripts (Fig. 1) and especially on its protein release: CLL5 protein concentrations were downregulated in 13 from 14 (93\%) cultures treated by Dx $(p<0.01)$. TNF- $\alpha$-induced transcripts were reduced by Dx; however, the difference did not attain significance. The suppression of CCL5 by CyA was observed on the mRNA level $(p=0.02)$. By contrast, CyA had virtually no effect on the level of CCL 5 protein in cell culture supernatant. Px did not influence the expression and release of the CCL5 chemokine from bronchoalveolar cells; a uniform pattern was observed in the majority of in vitro experiments with this drug.

When subanalysis was performed with the data obtained in bronchoalveolar cells from the patients with sarcoidosis, the pattern of modulation of chemokine expression and production by all three investigated drugs was nearly identical to that in the DLD group as a whole: Dx suppressed TNF- $\alpha-$ induced expression of CCL5 protein in bronchoal-

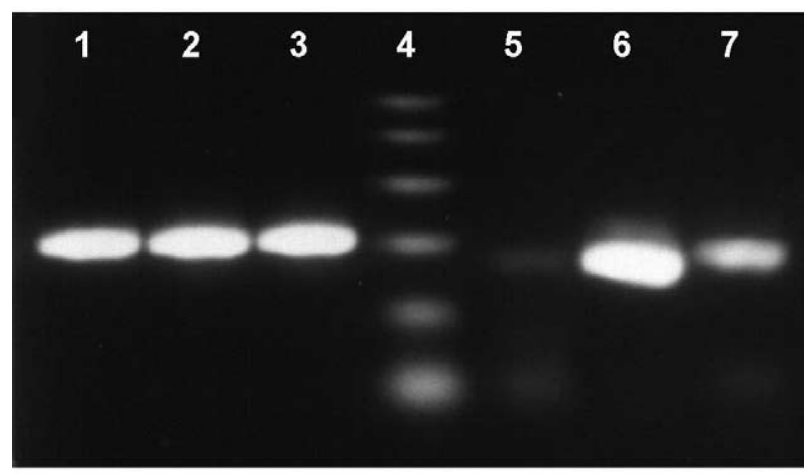

FIG. 1. The effect of Dx on the TNF- $\alpha$-induced expression of CCL5 mRNA in bronchoalveolar cells (a representative example). The products of CCL5-specific PCR are shown in lanes 5-7 (lane 5, non-stimulated culture; lane 6, TNF- $\alpha$ stimulated culture; lane 7, culture co-stimulated with TNF- $\alpha$ and Dx). Beta-actin amplicons in lanes 1-3 documents that equal amounts of RNA were extracted from the cultures (in the same order from left to right). Lane 4, molecular weight markers (PCR marker; Promega); bands are from the top $1000-750-500-300-150-50$ bp. veolar cells of $9 / 10(90 \%)$ patients with sarcoidosis (Fig. 2).

Modulation of TNF- $\alpha$-induced CCR 5 mRNA expression was investigated in a subset of patients. CCR5 transcripts were downregulated in six of seven (86\%) cultures treated by Dx and in five of six (83\%) cultures in the presence of CyA (Dx, $p=0.02$; CyA, $p=0.04 ;$ Table 3).

\section{Discussion}

In this study, we were interested how three drugs used or tested in the therapy of DLD, namely Dx, CyA and $\mathrm{Px}$, modulate expression of CCL5 (RANTES), which has been implicated in pathogenesis of DLD. We studied their effect on TNF- $\alpha$-induced expression of CCL 5 mRNA and release of CCL 5 protein by bronchoalveolar lavage fluid cells from patients with DLD in vitro. We also explored whether Dx and CyA modulate expression of mRNA for the RANTES receptor, CCR5.

The concentration of all studied drugs was selected to correspond to therapeutic levels in vivo. We observed that $10^{-6} \mathrm{M}$ of $\mathrm{Dx}$, the drug of first-line in the therapy of DLD, inhibited TNF- $\alpha$-induced CCL 5 mRNA expression and especially protein release by bronchoalveolar cells. It has been previously reported that CCL5 plays an important role in the pathogenesis of sarcoidosis ${ }^{9}$ and also of other DLD. ${ }^{10}$ Our current findings indicate that the beneficial effect of Dx in the therapy of DLD can be explained by suppression of expression CCL5 mRNA and namely protein production. From general point of view, our observations also correspond to the results of Kwon et al., ${ }^{18}$ who described a suppressive effect of Dx on CCL5 mRNA and protein in lung epithelial cells.

By contrast to Dx, CyA was able to effectively downregulate CCL5 at the transcript but not at protein level. The discrepancy between significant reduction of chemokine mRNA expression by CyA and virtually no effect of this immunosupressive on 


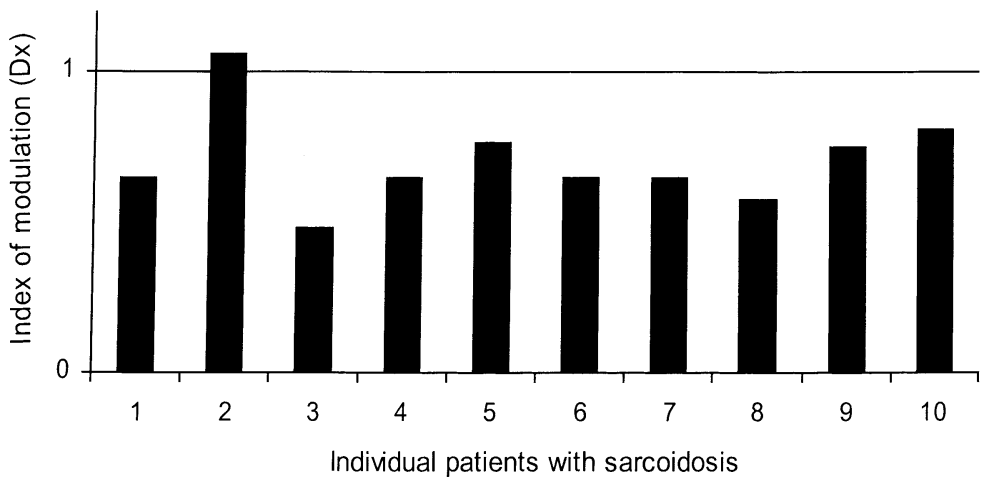

FIG. 2. Effect of Dx on TNF- $\alpha$-induced production of CCL5 protein in bronchoalveolar cells from 10 patients with sarcoidosis. CCL5 protein expression in cultures with TNF- $\alpha$ alone is used as a reference value (normalised to 1.00; horizontal line). The modulatory effect of $D x$ is expressed as individual relative values (index of modulation) for each patient. For details, see Materials and methods. Presented as the index of modulation in cultures treated with TNF- $\alpha$ dexamethasone versus cultures with TNF- $\alpha$ alone, $p<0.01$.

subsequent release of CCL5 protein from bronchoalveolar cells in vitro fits with the unsuccessful outcome of clinical experiments in the therapy of sarcoidosis - the most frequent and representative DLD. ${ }^{13}$ A possible explanation for the inability of CyA to alter CCL5 protein production in both in vitro and in vivo settings is its more selective action directed mainly at activated $\mathrm{T}$ lymphocytes. ${ }^{11}$ However, there are not only lymphocytes, but also alveolar macrophages and granulocytes in the bronchoalveolar space of patients with DLD, and these may not be influenced by CyA. By contrast, the effect of glucocorticoids is more complex, and includes several types of immune cells. ${ }^{23}$ Alternatively, the observed discrepancy between effects of CyA on CCL 5 mRNA and protein levels can also be due to possible effects of post-transcriptional and post-translational regulation mechanisms including release and metabolism of CCL5 protein. ${ }^{24}$

The immunomodulatory properties of the third studied drug, Px, have been described recently. Its immunomodulatory mechanism is based on the inhibition of TNF- $\alpha$ production..$^{15,16}$ In this study, neither CCL5 mRNA nor protein was altered in the cultures influenced by Px $(20 \mu \mathrm{g} / \mathrm{ml}$ of culture). The data suggest that Px has not a direct influence on expression and protein release of chemokine CCL5 in vitro. Px was, however, successfully used for treatment of patients with progressing sarcoidosis. ${ }^{17}$ It is, therefore, possible that $\mathrm{Px}$ beneficial effects are limited either to subgroup of patients with active disease that were under-represented in our study group, or that this drug targets different pathogenetic mechanisms than cellular influx regulated by chemokines.

We are aware of the heterogeneity of the group of DLD, which were represented in our study. However, we tried to ensure that the composition of our group reflects real frequencies of individual DLD, with sarcoidosis and cryptogenic fibrosing alveolitis (CFA) as their most common representatives. In this regard it should be mentioned that the pattern of modulation of CCL5 production by bronchoalveolar cells was virtually identical when subanalysis was performed for sarcoidosis. This is important in the context of participation of CCL5 and of its receptor, CCR5, in the pathogenesis of this representative DLD. ${ }^{11}$ In this regard we would like to mention that analysis of the CCR5 mRNA expression showed downregulation of CCR 5 transcripts by Dx and CyA. To our knowledge, this is the first report of a suppressive effect of these drugs on CCR5 expression.

In summary, our findings suggest that, among the three studied drugs, Dx is the most effective inhibitor of CCL 5 chemokine production in the bronchoalveolar space of patients with DLD. This drug not only suppresses TNF- $\alpha$-induced CCL 5 protein release from bronchoalveolar cells, but also downregulates expression of mRNA for its receptor, CCR5. The data presented in this study, therefore, supports the use of corticosteroids in the therapy of DLD. This concept has been further supported by our recent observations of dexamethasone's suppressive effect on CCL19 (MIP-3beta), a recently described mediator of lymphocyte alveolitis in sarcoidosis. ${ }^{25}$

ACKNOWLEDGEMENTS. The authors thank Dr Szotkowska for her contribution to protein analysis by ELISA. The help of Ms A. Vevodova and of the staff of Bronchology Unit of Department of Respiratory medicine is gratefully acknowledged. The work was supported by the Czech Ministry of Health (IGA grant no. 3768-3 to M.P.). Partial funding was obtained from the Czech Government fund (MSMT J14/98.151100002) and also from a Travel Fellowship granted to M.P. by the British Society for Immunology. Part of this work was presented at the 1st International WASOG Conference on Diffuse Lung Disease, Venice, 7-9 June 2001.

\section{References}

1. Baggiolini M. Chemokines and leukocyte traffic. Nature 1998; 392: $565-568$.

2. Mahalingam S, Karupiah G. Chemokines and chemokine receptors in infectious diseases. Immunol Cell Biol 1999; 77: 469-475.

3. Antoniades HN, Neville-Golden J, Galanopoulos T, Kradin RL, Valente AJ, Graves DT. Expression of monocyte chemoattractant protein 1 mRNA in human idiopathic pulmonary fibrosis. Proc Natl Acad Sci USA 1992; 89: $5371-5375$. 
4. Standiford TJ, Rolfe MW, Kunkel SL, et al. Macrophage inflammatory protein-1 alpha expression in interstitial lung disease. J Immunol 1993; 151: $2852-2863$

5. Monti G, Magnan A, Fattal M, et al. Intrapulmonary production of RANTES during rejection and CMV pneumonitis after lung transplantation. Transplantation 1996; 61: 1757-1762.

6. Keane MP, Standiford TJ, Strieter RM. Chemokines are important cytokines in the pathogenesis of interstitial lung disease. Eur Respir J 1997; 10: 1199-1202.

7. Schall TJ, Jongstra J, Dyer BJ, Jorgensen J, Clayberger C, Davis MM, Krensky AM. A human T cell-specific molecule is a member of a new gene family. I Immunol 1988; 141: 1018-1025.

8. Schall TJ, Bacon K, Toy KJ, Goeddel DV. Selective attraction of monocytes and $\mathrm{T}$ lymphocytes of the memory phenotype by cytokine RANTES. Nature 1990; 347: 669-671.

9. Petrek M, Pantelidis P, Southcott AM, et al. The source and role of RANTES in interstitial lung disease. Eur Respir J 1997; 10: 1207-1216.

10. Kodama N, Yamaguchi E, Hizawa N, et al. Expression of RANTES by bronchoalveolar lavage cells in nonsmoking patients with interstitial lung diseases. Am J Respir Cell Mol Biol 1998; 18: 526-531.

11. Petrek M, Gibejova A, Drabek J, Mrazek F, Kolek V, Weigl E, du Bois RM CC chemokine receptor 5 (CCR5) mRNA expression in pulmonary sarcoidosis. Immunol Lett 2002; 80: 189-193.

12. Lee JI, Burckart GJ. Nuclear factor kappa B: important transcription factor and therapeutic target. J Clin Pharmacol 1998; 38: $981-993$.

13. Wyser CP, van Schalkwyk EM, Alheit B, Bardin PG, Joubert JR. Treatment of progressive pulmonary sarcoidosis with cyclosporin A. A randomized controlled trial. Am J Respir Crit Care Med 1997; 156: 1371-1376.

14. Entzian P, Bitter-Suermann S, Burdon D, Ernst M, Schlaak M, Zabel P. Differences in the anti-inflammatory effects of theophylline and pentoxifylline: important for the development of asthma therapy? Allergy 1998; 53: 749-754.

15. Marques LJ, Zheng Puolakis L, Guzman JN, Costabel U. Pentoxifylline inhibits TNF-alpha production from human alveolar macrophages. Am J Respir Crit Care Med 1999; 159: 508-511.

16. Poulakis N, Androutsos G, Kazi D, et al. The differential effect of pentoxifylline on cytokine production by alveolar macrophages and its clinical implications. Respir Med 1999; 93: 52-57.
17. Zabel P, Entzian P, Dalhoff K, Schlaak M. Pentoxifylline in treatment of sarcoidosis. Am J Respir Crit Care Med 1997; 155: 1665- 1669.

18. Kwon OJ, Jose PJ, Robbins RA, Schall TJ, Williams TJ, Barnes PJ Glucocorticoid inhibition of RANTES expression in human lung epithelial cells. Am J Respir Cell Mol Biol 1995; 12: 488-496.

19. Hashimoto S, Gon Y, Matsumoto K, Takeshita I, Maruoka S, Horie T Inhalant corticosteroids inhibit hyperosmolarity-induced, and cooling and rewarming-induced interleukin- 8 and RANTES production by human bronchial epithelial cells. Am J Respir Crit Care Med 2000; 162: $1075-1080$

20. Petrek M, Kolek V. T-lymphocyte subpopulations in bronchoalveolar lavage in pulmonary sarcoidosis and other interstitial pulmonary diseases. Cas Lek Ces 1993; 132: 365-368 [in Czech].

21. Mrazek F, Petrek M. Processing of mRNA from human leukocytes by biomagnetical separation: comparison with current methods of RNA isolation. Acta Univ Palacki Olomouc Fac Med 1999; 142: 23-28.

22. Petrek M. Analysis of chemokine gene expression in lung cells by polymerase chain reaction. Acta Univ Palacki Olomouc Fac Med 1999; 142: $127-134$.

23. Marx J. How the glucocorticoids suppress immunity. Science 1995; 270: $232-233$.

24. Owais M, Arya SK. Antiviral chemokines: intracellular life of recombinant C-C chemokine RANTES. J Hum Virol 1999; 2: 270-282.

25. Gibejova A, Mrazek F, Subrtova D, et al. Expression of macrophage

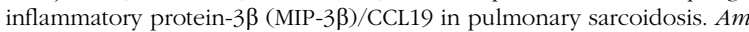
J Respir Crit Care Med 2003; 167: 1695-1703 [epub: www.ajrccm.org doi: $10.1164 / \mathrm{rccm} .200205-487 \mathrm{OC}]$.

26. Garcia JE, de Cabo MR, Rodrigues FM, Losada JP, Lopez AJ, Arellano JL. Effect of cyclosporin A on inflammatory cytokine production by U937 monocyte-like cells. Mediat Inflamm 2000; 9: 169-174.

\section{Received 14 May 2003 \\ Accepted 3 June 2003}




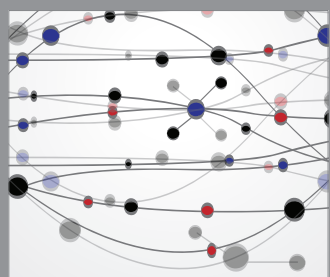

The Scientific World Journal
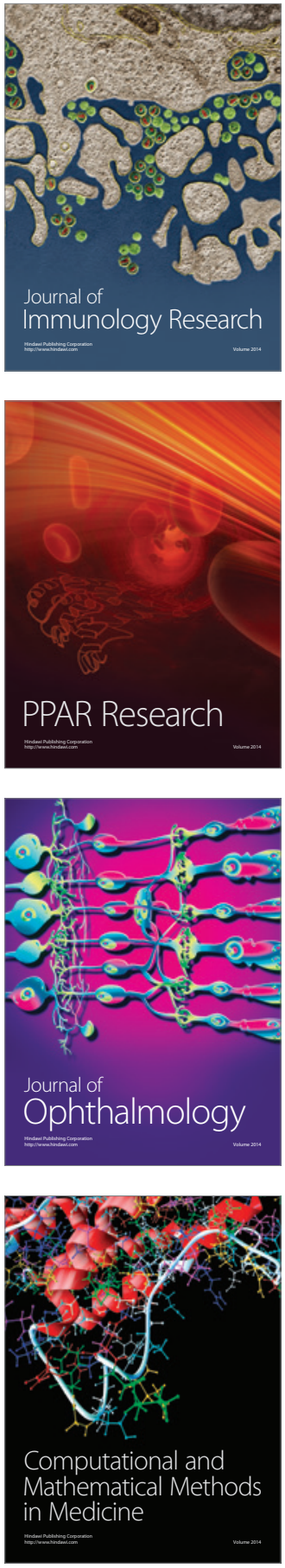

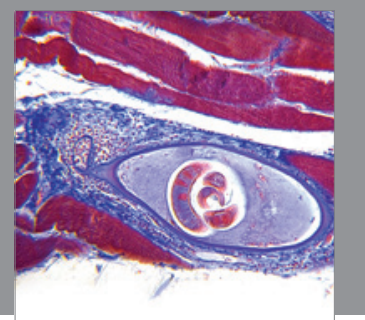

Gastroenterology

Research and Practice
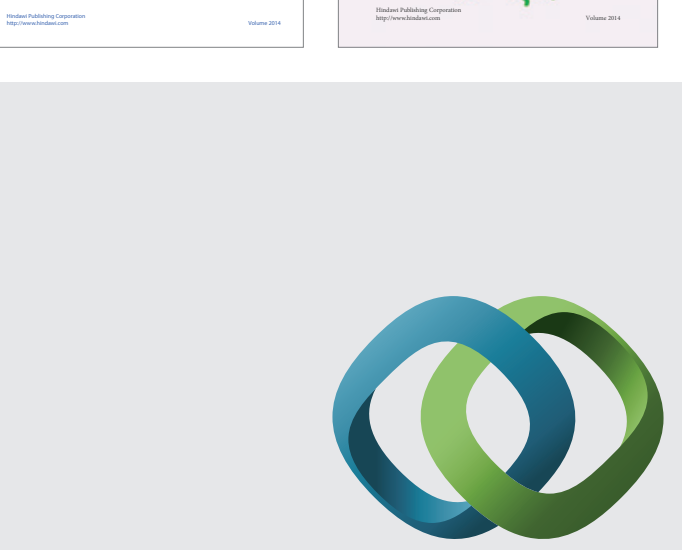

\section{Hindawi}

Submit your manuscripts at

http://www.hindawi.com
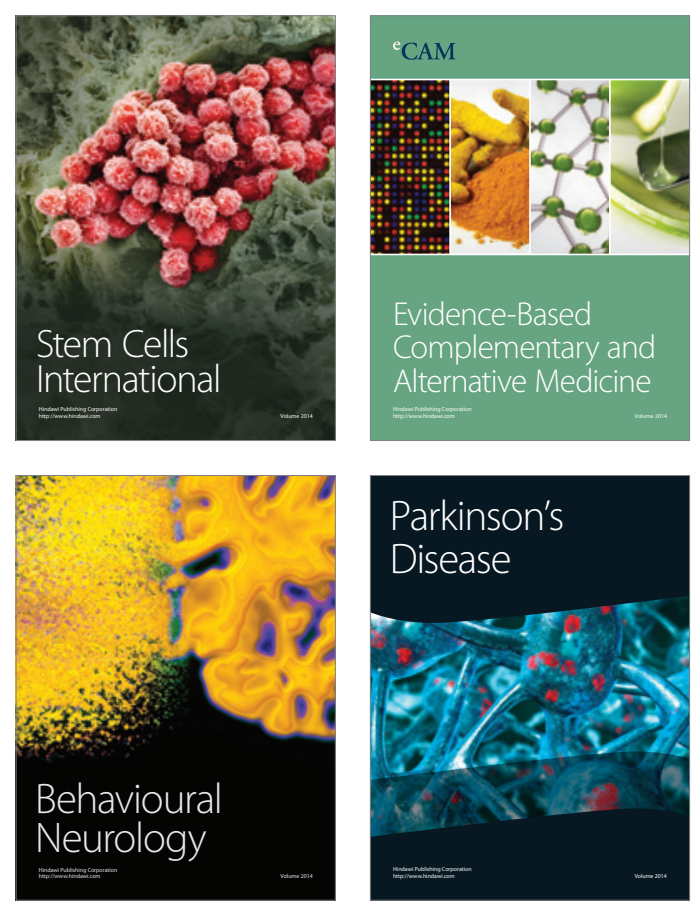

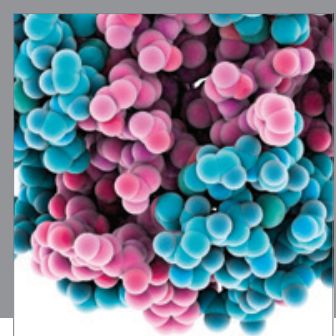

Journal of
Diabetes Research

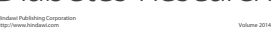

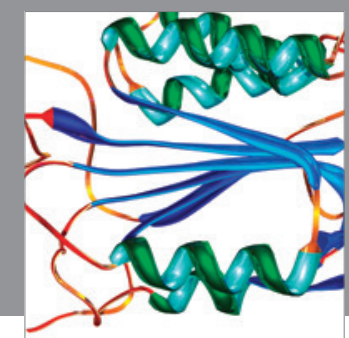

Disease Markers
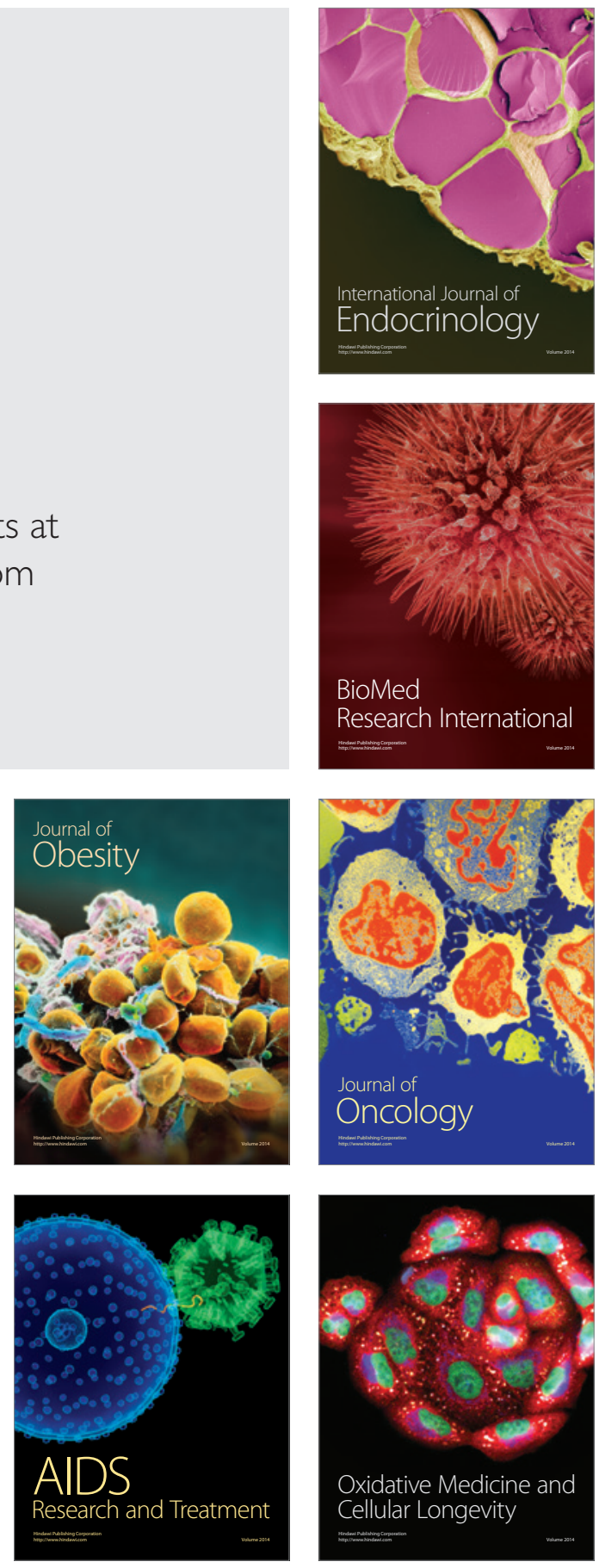